\title{
Reform and Innovation of "Introduction to E-commerce" Curriculum Teaching Based on Entrepreneurship Education
}

\author{
Mengqing Feng ${ }^{1,2, a}$, \\ ${ }^{1}$ School of Information Engineering, Zhengzhou University of Industrial Technology, \\ Zhengzhou Henan 451150, PR China \\ ${ }^{2}$ Machine learning and Data researching Institute, Zhengzhou University of Industrial Technology, \\ Zhengzhou Henan 451150, PR China \\ a903901419@qq.com
}

Keywords: Entrepreneurship education; E-Commerce; Course teaching; Internet+

\begin{abstract}
E-commerce is an emerging industry with highly entrepreneurial awareness, E-commerce venture has become the focus of entrepreneurship education in Colleges and universities, providing a broad stage for college students. Take "Introduction to e-commerce as a starting point, this paper constructs the curriculum teaching content based on entrepreneurship education, establishes the practical teaching system with actual combat, developments the three-dimensional network teaching resources in order to train the students to possess the pioneering consciousness, spirit and ability, which combines entrepreneurship education with curriculum teaching.
\end{abstract}

\section{Introduction}

"Introduction to e-commerce" as e-commerce professional[1-4] basic course, is an involved, information technology, computer network security technology, electronic payment, marketing, logistics management, and other multi-disciplinary comprehensive its course. The course of the study effect directly affect the subsequent course of study, which requires the e-commerce professional teachers must carry out teaching reform, "introduction to e-commerce" will venture education[5-8] into the teaching, cultivate students' pioneering consciousness and creative ability.

\section{Analysis of teaching status of "introduction to e-commerce"}

The teaching content is updated slowly. The content of the teaching material is slow, the content of the teaching and the innovation are insufficient to adapt to the rapid development of e-commerce.

The practice teaching link is weak. "Introduction to e-commerce" involves a large number of new concepts that are abstract and difficult to understand, and students are generally bored with the curriculum.

Practice teaching is the students under the guidance of teachers, through the multimedia presentation, web browsing, case analysis, simulation, online mall management manner, students failed to combine theory with practice, the lack of practical ability.

The teaching method is simple. Is given priority to with the teacher lectures, multimedia teaching and case teaching, through the exercises after class assignment, strengthen students consolidate of knowledge, the teaching method is simple, single teaching means, don't adapt to the requirement of modern students' learning.

Teaching evaluation is single. "Introduction to e-commerce" is a practical curriculum, the traditional way of teaching evaluation mainly USES the unified examination paper evaluation, evaluation of the knowledge in the aspect of theoretical basis, it is difficult to quantitative assessment of practical skills, not objectively reflect the teachers' teaching level, is also unable to measure students' comprehensive ability in an all-round way. 


\section{"Introduction to e-business" course teaching reform objectives}

Teaching reform of "introduction to e-commerce" overall goal: to cultivate students' innovative ability as the goal, to build based on entrepreneurship education course teaching content, establishing practical teaching system, practical development of three-dimensional network of teaching resources, form rich course characteristics and practical effect good demonstration course;

Innovative teaching methods and means to achieve the results and experience worthy of reference and promotion;

We should build a curriculum teaching team with high scientific research ability and teaching level, and realize the docking of curriculum teaching and enterprise demand and professional standard.

\section{"Introduction to e-commerce" course teaching reform ideas}

Transformation of curriculum positioning. The mobile Internet era, college attaches great importance to the students' innovation ability, "introduction to e-commerce" curriculum into all the basis of professional course, help develop "public entrepreneurship, peoples innovation" of the powerhouse.

At the same time, according to different professional integration of course contents, such as outstanding network marketing management major, tourism professional outstanding electrical business hotel, engineering professional outstanding network technology and so on, to promote "Internet +" [9-10]new formats form.

Transformation of overall thinking. Establish enough knowledge, the ability of application priority, innovation reform train of thought, as a bridge to knowledge, on the basis of practice, through the understanding of "knowledge and summarized the formation of the practical skills is a creative thinking play a entrepreneurial activity of the implementation of the" four stages such as Figure.1, from theory to practice, from the classroom to the workplace, from books to the smooth transformation of the market.

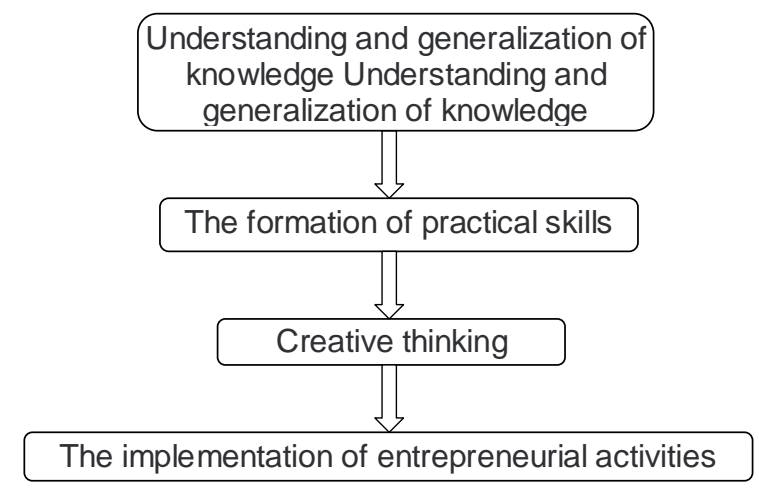

Figure 1. Transformation of ideas

Adjustment of curriculum standards. To regulate and feasible curriculum standard, organic restructuring and optimization of teaching content, according to the requirements of enterprises, professional standards, to fine-tune curriculum standard on a regular basis, cut and outdated content, increase the new knowledge.

Teachers in the preparation stage based on curriculum standards, formulate the corresponding teaching scheme based on the characteristics of different professional, both considering the course knowledge system of integrity, and considering the different professional knowledge of the course content focuses on.

Transformation of teaching methods. "Introduction to e-commerce" project lead type teaching mode, through the task driven teaching, case teaching, the role of division of simulated teaching method, intuitive, vivid display of teaching content, improve the efficiency of classroom teaching; 
Timely assess the students' grasp of the knowledge, adjust and improve the teaching progress, and improve the effect of classroom teaching.

Transformation of evaluation method. The teaching evaluation method combining process evaluation and outcome evaluation is used to evaluate students' innovative entrepreneurial ability. Through the way of obtaining a "to instead of, decorate a design type or entrepreneurial training project, based on task drive, lets the student group, grade can be done from three aspects, $20 \%$ performance and work at ordinary times, experiment practice, $30 \% 50 \%$ business planning book.

\section{Focus on the reform of "introduction to electronic commerce"}

Teaching content project." Introduction to e-commerce" the selection of teaching contents in order to "Internet + " contest of college students' innovative undertaking, e-business entrepreneurship competition as the backing, combined with the teaching material content, design of eight teaching project, 25 teaching tasks, teaching content followed from easy to difficult, from simple to complex sequence, from single to the integrated application of technology, through the guidance of project teaching, complete the startup project planning book.

Practical teaching practice. Encourage students to open personal online stores. Taobao, patting and other $\mathrm{C} 2 \mathrm{C}$ websites offer free shops, with little expense, flexible trading methods and very little upfront investment, suitable for students at school. Students by setting up personal online store, form a business simulation company, group, set up the company department collaboration to carry out market research, writing business plan book, implement entrepreneurial projects, operations management, and other activities, to cultivate the students' application ability, organization ability, team cooperation ability, lay a foundation for future business. participating in all kinds of electronic business competitions, the living soul "Isaiah" is an important means to launch the education of e-commerce entrepreneurship, and the school actively organizes the e-business competition at all levels. Give priority to with a team competition, the winners on behalf of the school take part in the national contest of electronic commerce, "Internet + " contest of college students' innovative undertaking, the national mobile commerce application ability competition, the national college students' network marketing ability show competition, the national network entrepreneurship contest and other activities, training students independent thinking, communication, coordination, social resources to solve the actual problem ability. strengthening the construction of e-commerce entrepreneurship base. In this paper, we will introduce entity enterprises to explore "base + students", "enterprise + students", "project + students", studio and entity companies. To carry out entrepreneurial activities with the help of physical enterprises and reduce the risk of e-commerce entrepreneurship among students in school; Students should be encouraged to take up the internship in small and medium-sized enterprises with the potential of development, to help enterprises realize e-commerce and to provide students with the best training platform. At the same time, the school improved the e-business startup support policy to help students, set up the startup company, let the students carry on the personalized development, accumulate the actual experience, familiar with the enterprise operation mode.

The teaching resources are materialized. Construction of featured school textbooks. Organization professional teachers, industry experts, in accordance with the standards, job competence needs, establish innovative entrepreneurship as the goal, project drive oriented, based on the practical ability of characteristic school-based teaching materials, and complete the form a complete set of practical instruction, teachers' teaching and students' learning instructions, etc, formation course features, for the connection of course teaching and enterprise requirements, professional standards. Establishment of high-quality resource sharing courses. Establish the fine resource sharing "introduction to e-commerce", equipped with a variety of teaching resources, including the curriculum standard, electronic lesson plans, video, putted forward, the examination, practice instruction, competition scheme, vocational qualification certificate, etc, make the teaching media from a single media to a variety of media; To transform teaching activities from one direction of information to two-way interaction; Enable students to learn from individual learning to learn from cooperative learning. make full use of network resources. Under the guidance of teachers, 
network and information technology are integrated into daily teaching, and students are encouraged to conduct market research using search engines, Internet databases, portal websites and enterprise websites. Encourage students to open stores on $\mathrm{C} 2 \mathrm{C}$ e-commerce platforms such as taobao and paipai.com; Students are encouraged to use platforms such as alibaba to release information about the supply and demand of enterprises' commodities, and make network resources a tool for students to consciously learn, find themselves and explore independently.

\section{"Introduction to e-commerce" entrepreneurship education}

Guide students to correctly understand e-business entrepreneurship. Special lectures will be given to students to understand the internal and external environment and development prospects of e-commerce entrepreneurship. Strengthen the typical education, take the "go out, please come in" way, let the students know the successful people's entrepreneurial history; The school tries to use radio, school newspaper, TV, Internet and other media to carry out the business promotion.

Strengthen teacher e-commerce entrepreneurship education. Strengthen teachers e-commerce business training, teaching lectures about entrepreneurship education experts, entrepreneurs, for teachers to understand the electronic commerce development status and trends, improve teachers' level of e-commerce skills. Encourage teachers throw pure theoretical teaching, to combine theory with practice, to adjust their own knowledge, ability and quality structure, strengthen the intersection between different disciplines, promote modernization of teaching mode, teaching method and teaching means.

Play the role of funds in e-commerce entrepreneurship education. Broaden the channels of funding sources, through the government, enterprises, social charity institutions, alumni, such as access to funding, the school he founded related businesses, get more money, to provide more resources and platform for entrepreneurship education, strong feasibility of entrepreneurial planning project of discretionary investment to give the part of the loan or to support; Financial rewards for individuals or teams who have achieved excellent results in electronic business competitions or scientific research projects; For entrepreneurial individuals or organizations to reward outstanding achievements, support the project, such as for operating online successful students, schools can reward free shops, promote the combination of the network and the real operation.

\section{References}

[1] Xiao-Qian M A. The Discussion of E-commerce Professional Reform Thinking Based on the Full Penetration Type[J]. (2016).

[2] Y.Wang, X.Zhang. The Social Demand Analysis on E-commerce Professional Talents[J]. Agriculture Network Information, (2015).

[3] B.Wang. New Ideas on the Training of E-commerce Professional Talents in Higher Vocational Colleges under the Development of Cloud Computing[J]. Wireless Internet Technology, (2015).

[4] J.Jie, X.Wan and Y.Fang. E-commerce Professional Training Mode in Universities of Information Technology[C]// International Conference on E-Business and E-Government. IEEE Computer Society, (2012) No.12,P.412-420.

[5] D.M.Shi. Research and practice of teaching the computer core courses in joint-venture education[J]. Journal of Zhenjiang College, (2009) No.18,p326-333.

[6] S.F.Sun, Z.Y.Re. Attach importance to practice link and promote venture education system of institutions of higher learning[J]. Journal of Zhejiang University of Science \& Technology, (2008).

[7] Q.W.Zhang. Study on Undergraduates' Venture Education in a Context of Global Urbanization in Dalian[J]. Journal of Dalian University, (2013) No.14(1),p.485-498.

[8] D.L.Sun, Y.Li, Q.X.Zhou, et al. The Research of the Characteristic Specialized Subject of E-Commerce on Informatization Entrepreneurial Venture[J]. Applied Mechanics \& Materials, (2013), p.411-414,p.2284-2287.

[9] C.J.Wang. Study on the Construction of "Internet+" Under the Background of Yunnan Ethnic 
Areas of E-Commerce Specialty of Higher Vocational Education Curriculum System[J]. Computer Knowledge \& Technology, (2017).

[10]Z.Dong. Strategy for Rural E- commerce Development in Qujing Under the "Internet + "[J]. Journal of Qujing Normal University, (2016). 